\title{
Damage to Chromosomal and Plasmid DNA by Toxic Oxygen Species
}

\author{
By MAJA ROZENBERG-ARSKA, ${ }^{1,2 *}$ B. SWEDER VAN ASBECK, ${ }^{1}$ \\ THEODORUS F. J. MARTENS ${ }^{1}$ AND JAN VERHOEF ${ }^{1,2}$ \\ ${ }^{1}$ Department of Microbiology, Catharijnesingel 59, 3511 GG Utrecht, The Netherlands \\ ${ }^{2}$ Department of Clinical Bacteriology, University Hospital, Catharijnesingel 101, \\ 3511 GV Utrecht, The Netherlands
}

(Received 21 May 1985; revised 24 July 1985)

\begin{abstract}
Bacterial DNA was incubated with xanthine plus xanthine oxidase plus excess iron as an oxygen-species-generating system, and DNA injury was measured by agarose gel electrophoresis and by the ability of the DNA to transform competent bacteria. After 5 to 10 min incubation, the covalently closed circular form of plasmid DNA was converted into the open circular form, and after $30 \mathrm{~min}$, to some extent into the linear form. Biological activity, measured as the number of transformed bacteria, decreased rapidly after 10 min incubation. Incubation of chromosomal DNA with the enzymic oxygen-species-generating system resulted in the degradation of DNA to small fragments within about $1 \mathrm{~h}$. Excess iron was essential for the damaging effect of xanthine plus xanthine oxidase. Damage to DNA could be prevented by oxygen scavengers such as superoxide dismutase, catalase, mannitol and thiourea. Our results suggest that hydroxyl radical is the injurious oxidant for bacterial DNA, and that it can mediate physicochemical as well as biological alterations in DNA.
\end{abstract}

\section{INTRODUCTION}

Toxic oxygen species play an important role in the microbicidal activity of phagocytic cells, such as polymorphonuclear leucocytes and monocytes (Klebanoff, 1975; McPhail et al., 1981). Not much is known about the precise mechanism by which toxic oxygen species kill and contribute to the degradation of micro-organisms after phagocytosis (Elsbach, 1980). Recently we presented evidence that bacterial DNA is degraded by nucleases present in serum (Rozenberg-Arska et al., 1984a) and in mononuclear leucocytes (Rozenberg-Arska et al., 1984b). We have now extended these studies to answer the question as to whether toxic oxygen metabolites are capable of reacting with bacterial nucleic acid and whether they contribute to the degradation of DNA. Damage to DNA was visualized in gels and the loss of biological activity of DNA was determined by the capacity of DNA to transform recipient bacteria. Our results show a rapid change in the structure of bacterial DNA during incubation with the oxygen-species-generating system xanthine plus xanthine oxidase (Beauchamp \& Fridovich, 1970). These changes, which lead to loss of biological activity of the DNA, occurred only in the presence of excess iron, suggesting involvement of ${ }^{\circ} \mathrm{OH}$.

\section{METHODS}

Reagents. Xanthine was from Sigma. Xanthine oxidase (Sigma; buttermilk; specific activity approximately $0 \cdot 7$ units $\mathrm{mg}$ protein $\left.{ }^{-1}\right)$ was prepared at a concentration of $0 \cdot 1$ units $\mathrm{ml}^{-1}$ in TE buffer $(10 \mathrm{~mm}-\mathrm{Tris} / \mathrm{HCl}$ with $0 \cdot 1 \mathrm{mM}$ EDTA; pH 8.0). Catalase [Sigma; bovine liver; EC 1.11.1.6. 33900 units (mg protein) ${ }^{-1}$ ] was used at a concentration of $500 \mu \mathrm{g} \mathrm{ml}^{-1}$ in TE buffer. Superoxide dismutase (SOD) [Sigma; bovine blood type I; EC $1.15 .1 .1 ; 2.8$ units (mg protein) $)^{-1}$ ] was used at a concentration of $100 \mu \mathrm{g} \mathrm{ml}^{-1}$. Mannitol (OPG, Utrecht, The

Abbreviation: SOD, superoxide dismutase. 
Netherlands), and thiourea (BDH), were dissolved in TE buffer and used at a concentration of $100 \mathrm{mM}$. $\mathrm{Fe}(\mathrm{III})$ citrate (Merck) was dissolved immediately before use in distilled water at a concentration of $0.2 \mathrm{M}$.

Isolation of chromosomal and plasmid DNA. Chromosomal and plasmid DNA were isolated from Escherichia coli K12 strain PC2166 harbouring plasmid RSF1030 (molecular weight $5.5 \times 10^{6}$ ) coding for ampicillin resistance. Plasmid DNA was isolated by the rapid alkaline extraction procedure described by Birnboim \& Doly (1979), and subsequently dissolved in $100 \mu 1$ distilled water. Chromosomal DNA was isolated according to the method of Cosloy \& Oishi (1973), and subsequently dissolved in an appropriate volume of $1 / 10$ strength standard saline citrate ( $15 \mathrm{~mm}-\mathrm{NaCl} / 1 \cdot 5 \mathrm{~mm}$-trisodium citrate).

Incubation of chromosomal and plasmid DNA in xanthine plus xanthine oxidase. The standard reaction mixture consisted of $2 \mathrm{~mm}$-xanthine, $0 \cdot 1$ units xanthine oxidase $\mathrm{ml}^{-1}$, with or without $0.2 \mathrm{~mm}-\mathrm{Fe}$ (III) citrate in TE buffer in a total volume of $0.5 \mathrm{ml}$ at $\mathrm{pH} 7.5$.

Breakdown of DNA assay. Chromosomal DNA at a concentration of $644 \mu \mathrm{g} \mathrm{ml}^{-1}$, or plasmid DNA in concentration of $450 \mu \mathrm{g} \mathrm{ml}^{-1}$, was incubated in xanthine plus xanthine oxidase with or without iron for different time intervals. The extent of degradation of the DNA molecules was measured by electrophoresis in agarose gels. The effect of the treatments on the biological activity of DNA was demonstrated by the capacity of DNA to transform competent recipient bacteria.

Agarose gel electrophoresis. This was used to visualize plasmid and chromosomal DNA after they had been incubated with toxic oxygen species for various time intervals. Electrophoresis was done in horizonatal slab gels (gel dimensions $14.5 \mathrm{~cm} \times 27 \mathrm{~cm} \times 3 \mathrm{~mm}$, with 16 slots), containing $0.6 \%(\mathrm{w} / \mathrm{v})$ agarose (type IV, Sigma) dissolved in electrophoresis buffer ( $40 \mathrm{~mm}$-Tris, $20 \mathrm{~mm}$-sodium acetate, 2 mM-EDTA, adjusted to $\mathrm{pH} 7.8$ with acetic acid). Both agarose and electrophoresis buffer contained ethidium bromide at a final concentration of $2 \mu \mathrm{g} \mathrm{ml}^{-1}$. Electrophoresis was done either for $4 \mathrm{~h}$ at $30 \mathrm{~mA}$ or overnight at $12 \mathrm{~mA}$. Gels were photographed under UV light $(360 \mathrm{~nm})$ using Polaroid type film (Kodak 667) with an orange 22 filter.

Transformation by chromosomal DNA. E. coli AM1095 ( $\left.\mathrm{Rec}^{+} \mathrm{Leu}^{-}\right)$was transformed by chromosomal DNA which had been incubated with the oxygen-species-generating system. The procedure was described by Bergmans et al., (1981).

Transformation by plasmid DNA. E. coli $\mathrm{K} 12 \mathrm{C} 600$ was transformed by plasmid DNA which had been incubated with the oxygen-species-generating-system. The procedure was a modification of that described in detail by Bergmans et al. (1981) and by Cosloy \& Oishi (1973).

Effect of the addition of scavengers to the oxygen-species-generating system on chromosomal and plasmid DNA. The influence of SOD, catalase, mannitol and thiourea on the toxic effects of the oxygen-species-generating system was studied. Chromosomal and plasmid DNA were incubated with xanthine plus xanthine oxidase in the presence of $\mathrm{Fe}$ (III) citrate with and without various oxygen radical scavengers for $2 \mathrm{~h}$ at $37^{\circ} \mathrm{C}$ at $\mathrm{pH} 7.5$. After incubation, part of the treated DNA was visualized in gels and the remainder was used to transform recipient bacteria.

Statistical analysis. The SEM was taken as an estimate of variance.

\section{RESULTS}

\section{Effect of the xanthine-xanthine oxidase system on the biological activity of plasmid and chromosomal DNA}

Xanthine plus xanthine oxidase had no injurious effect on plasmid DNA. After incubation, no changes in the physicochemical structure of the DNA were observed in gels. Also, plasmid DNA retained its biological activity. Plasmid DNA incubated with xanthine plus xanthine oxidase was able to produce $301 \pm 2 \cdot 5$ (mean \pm SEM) transformed colonies compared with $296 \cdot 2$ \pm 7.8 transformed colonies produced by control plasmid DNA (Table 1). However, in the presence of $\mathrm{Fe}$ (III) citrate, xanthine plus xanthine oxidase reduced the capacity of plasmid DNA to transform recipient bacteria significantly $(27.7 \pm 7.8$ vs $296.2 \pm 7.8)$.

To find out which toxic oxygen species generated by the system was responsible for the change in configuration and biological activity of plasmid DNA, scavengers of different oxygen species were used. When plasmid DNA was incubated with xanthine plus xanthine oxidase plus Fe(III) citrate in the presence of catalase or SOD, the number of transformants was $235.7 \pm 7.2$ and $159 \cdot 3 \pm 9 \cdot 2$, respectively, compared to $27.7 \pm 7.8$ when no catalase or SOD was added. This indicates that catalase or SOD prevents at least some toxic effect of xanthine and xanthine oxidase. Addition of either mannitol or thiourea also protected against the toxic effect of the oxygen-species-generating system on plasmid DNA (Table 1). Similar results were found when chromosomal DNA was incubated with xanthine plus xanthine oxidase (Table 1). The extent of the change in the DNA depended on the duration of the incubation period. After $15 \mathrm{~min}$ 


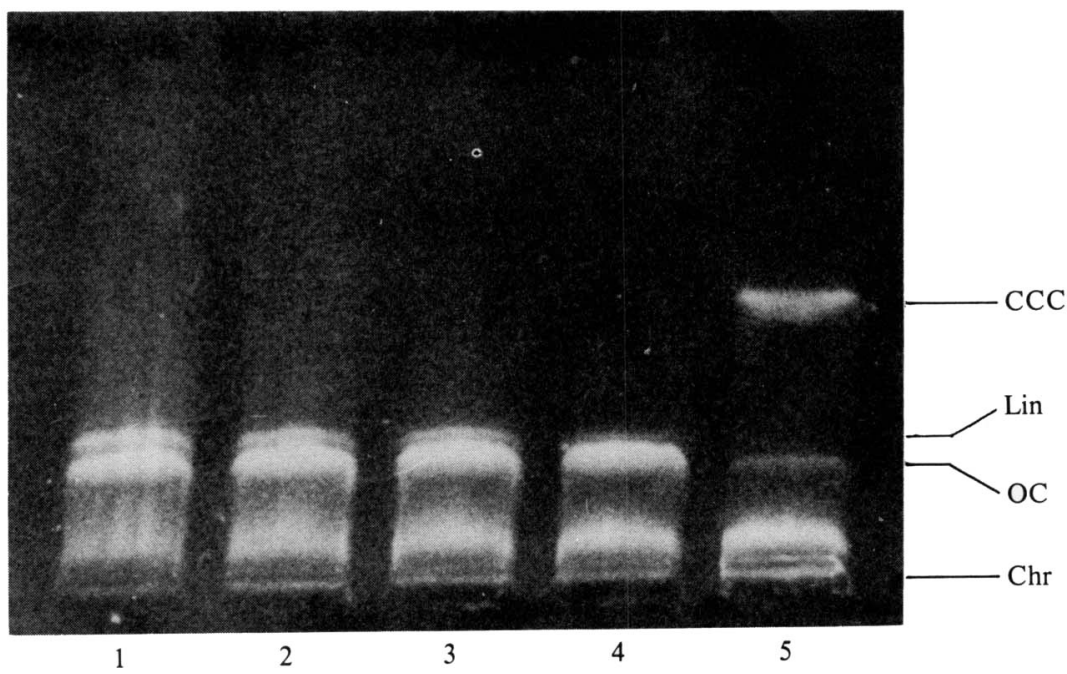

Fig. 1. Effect of xanthine plus xanthine oxidase plus Fe(III) citrate on plasmid DNA. A reaction mixture containing $2 \mathrm{mM}$-xanthine, 0.1 units xanthine oxidase $\mathrm{ml}^{-1}$ and $0.2 \mathrm{mM}-\mathrm{Fe}$ (III) citrate in a total volume of $0.5 \mathrm{ml} \mathrm{TE}$ buffer, $\mathrm{pH} \mathrm{7.5}$, was incubated with $9 \mu \mathrm{g}$ plasmid DNA at $37^{\circ} \mathrm{C}$. Tracks 1 to 4 , plasmid DNA after 30,60,90 and 120 min incubation; track 5, plasmid DNA incubated in the absence of the xanthine-xanthine oxidase-Fe(III) citrate system. Xanthine, xanthine oxidase or the combination of xanthine and xanthine oxidase without Fe(III) citrate had no effect on plasmid DNA. Abbreviations: CCC, covalently closed circular DNA; OC, open circular DNA; Lin, linear DNA; Chr, chromosom ${ }^{-1}$ DNA.

Table 1. Effect of xanthine, xanthine oxidase and Fe(III) citrate with and without scavengers on the capacity of plasmid and chromosomal DNA to transform recipient bacteria

Plasmid DNA $(18 \mu \mathrm{g})$ or chromosomal DNA $(9 \mu \mathrm{g})$ was incubated for $2 \mathrm{~h}$ at $37^{\circ} \mathrm{C}$ with the complete reaction mixture ( $2 \mathrm{~mm}$-xanthine, 0.1 units xanthine oxidase $\mathrm{ml}^{-1}, 0.2 \mathrm{mM}-\mathrm{Fe}$ (III) citrate, $\mathrm{pH} 7.5$; total vol. $1 \mathrm{ml}$ ) with additions and omissions as stated; the DNA was then used to transform recipient bacteria.

\section{Incubation conditions}

Complete reaction mixture

- Xanthine, xanthine oxidase and $\mathrm{Fe}(\mathrm{III})$ citrate

- Xanthine

- Xanthine oxidase

- Fe(III) citrate

+ Catalase $\left(500 \mu \mathrm{g} \mathrm{ml}^{-1}\right)$

+ Heated catalase $\left(15 \mathrm{~min}, 100^{\circ} \mathrm{C}\right)$

$+\operatorname{SOD}\left(100 \mu \mathrm{g} \mathrm{m}^{-1}\right)$

+ Heated SOD $\left(15 \mathrm{~min}, 100{ }^{\circ} \mathrm{C}\right)$

+ Mannitol (100 mM)

+ Thiourea (100 mM)

\begin{tabular}{|c|c|c|}
\hline \multicolumn{3}{|c|}{ No. of transformants* } \\
\hline Plasmid & DNA & Chromosomal DNA \\
\hline $27.7 \pm$ & $7 \cdot 8(3)$ & $50 \cdot 0 \pm 10 \cdot 8(4)$ \\
\hline $296 \cdot 2 \pm$ & $7 \cdot 8(9)$ & $784.4 \pm 38.8(9)$ \\
\hline $308 \cdot 3 \pm$ & $9 \cdot 2(3)$ & ND \\
\hline $304.0 \pm$ & $8 \cdot 7(3)$ & ND \\
\hline $301.0 \pm$ & $2 \cdot 5(3)$ & ND \\
\hline $235.7 \pm$ & $7 \cdot 2(3)$ & $763 \cdot 0 \pm 37 \cdot 1(3)$ \\
\hline $33 \cdot 3 \pm$ & $3 \cdot 3(3)$ & $33 \cdot 3 \pm 3 \cdot 3(3)$ \\
\hline $159 \cdot 3 \pm$ & $9 \cdot 2(3)$ & $773 \cdot 3 \pm 31.8(3)$ \\
\hline $31 \cdot 6 \pm$ & $1.6(3)$ & $35 \cdot 0 \pm 2.9(3)$ \\
\hline $161 \cdot 3 \pm$ & $5 \cdot 5(3)$ & $742 \cdot 5 \pm 23 \cdot 3(4)$ \\
\hline $228.0 \pm$ & $15 \cdot 6(3)$ & $760 \cdot 0 \pm 23 \cdot 6(4)$ \\
\hline
\end{tabular}

ND, Not determined.

* Mean \pm SEM of $(n)$ experiments.

incubation of plasmid DNA with Fe(III) citrate plus xanthine plus xanthine oxidase, a fall in the number of transformants from $435 \cdot 3 \pm 15 \cdot 4$ to $174 \cdot 0 \pm 6 \cdot 4$ colony forming units was observed. After 60 min incubation the number of transformants decreased to $52.5 \pm 4.7$ colony forming units (data not shown). A time-dependent breakdown of plasmid DNA could also be shown in agarose gels (Fig. 1). Degradation of DNA started with the change of the covalently closed circular (CCC) form into the open circular (OC) form; upon further incubation all DNA 


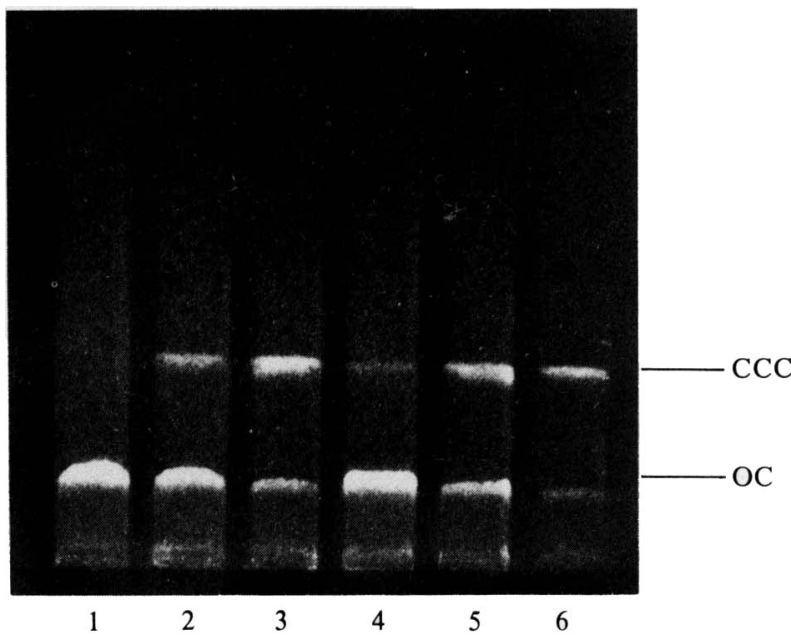

Fig. 2. Effect of xanthine plus xanthine oxidase plus Fe(III) citrate on plasmid DNA in the presence of oxygen radical scavengers. Plasmid DNA was incubated with the reaction mixture described in the legend to Fig. 1, in the presence or absence of various oxygen radical scavengers. Track 1, no added scavenger; track 2 , plus catalase $\left(100 \mu \mathrm{g} \mathrm{ml}^{-1}\right)$; track 3 , plus SOD $\left(100 \mu \mathrm{g} \mathrm{ml}^{-1}\right)$; track 4 , plus mannitol $(100 \mathrm{mM})$; track 5 , plus thiourea $(100 \mathrm{mM})$; track 6, plasmid DNA incubated in the absence of the xanthine-xanthine oxidase-Fe(III) citrate system.

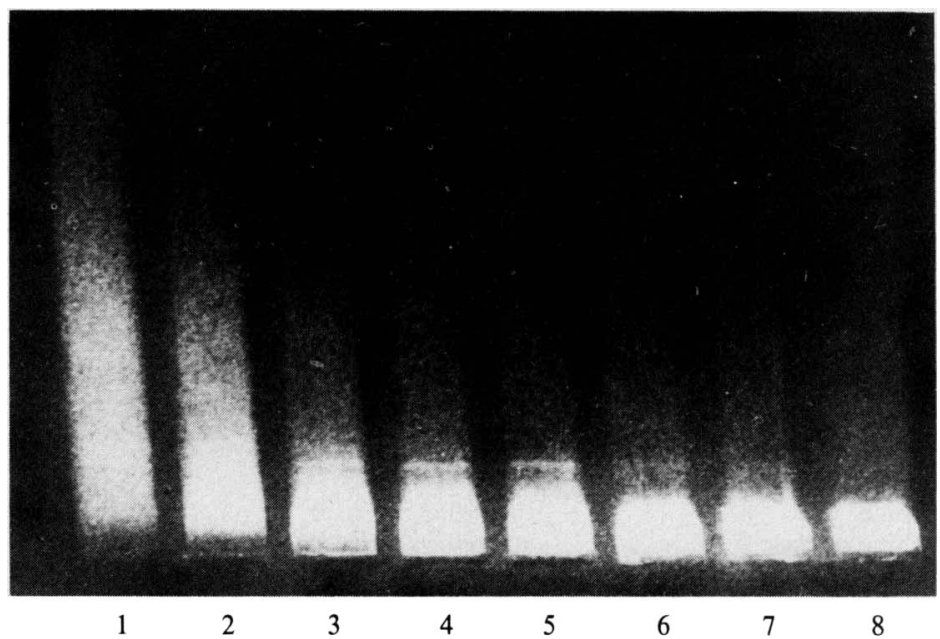

Fig. 3. Effect of xanthine plus xanthine oxidase plus Fe(III) citrate on chromosomal DNA. The reaction mixture described in the legend to Fig. 1 was incubated with $4.5 \mu \mathrm{g}$ chromosomal DNA at $37^{\circ} \mathrm{C}$. Tracks 1 to 6 , chromosomal DNA after $180,120,60,30,15$ and 5 min incubation; track 7 , chromosomal DNA incubated in the absence of xanthine oxidase; track 8, chromosomal DNA incubated in the absence of the xanthine-xanthine oxidase-Fe(III) citrate system.

changed to the $\mathrm{OC}$ form and, to some extent, to the linear form. It could also be observed that scavengers of toxic oxygen species diminished the effect of xanthine plus xanthine oxidase plus $\mathrm{Fe}$ (III) citrate on DNA degradation (Fig. 2). The addition of scavengers inhibited breakdown of plasmid DNA to different extents. Inhibition of DNA degradation was most pronounced when SOD was added to the xanthine-xanthine oxidase system, but thiourea, catalase and mannitol also showed significant effects. 
Degradation of chromosomal DNA was observed after about 15-30 min incubation. After $1 \mathrm{~h}$, only a smear of DNA was visible in the gel (Fig. 3). Addition of scavengers such as catalase, SOD, mannitol and thiourea inhibited this damaging effect (data not shown).

\section{DISCUSSION}

Reactive oxygen species have been implicated as a possible cause of bacterial cell death during phagocytosis (Babior et al., 1973; Klebanoff, 1975); they may also play an important role in the pathogenesis of tissue damage induced by radiation, inflammation (McCord, 1974) and ischaemia (McCord, 1985). They are known to be produced by the action of certain enzymes such as xanthine oxidase (Beauchamp \& Fridovich, 1970), and by polymorphonuclear and mononuclear phagocytes during the metabolic burst (Babior et al., 1973; Badwey \& Karnovsky, 1980; Klebanoff, 1975). The true contribution of reactive oxygen species to natural processes and in the development of pathological conditions is still largely unknown.

DNA is generally considered to be the most critical cellular target with regard to the lethal, carcinogenic and mutagenic effects of drugs, radiation and environmental chemicals; in several studies, the involvement of reactive oxygen species in DNA damage caused by irradiation (Xray, ionizing irradiation) or drug treatment has been inferred (Armel et al., 1977; Lesko et al., 1980; Myers, 1973; Rowley \& Halliwell, 1983). It has been shown that the hydroxyl radical leads to the formation of alkali-labile lesions in the DNA strands and to single strand breaks (Armel $e t$ al., 1977; Myers, 1973). Lesko et al. (1980) found that the degradation of DNA depended on the presence of $\mathrm{Fe}^{2+}$ ions. DNA binds $\mathrm{Fe}^{2+}$ and this complex is effective in catalysing $\mathrm{H}_{2} \mathrm{O}_{2}$ breakdown to yield OH. Chelation of iron prevented damage to the DNA (Sausville et al., 1978). In most studies, DNA damage was measured by assaying for nicks in the DNA molecule. We studied the effect of toxic oxygen species, generated by xanthine oxidase, on the physicochemical and biological activity of bacterial (chromosomal and plasmid) DNA. The xanthine-xanthine oxidase system reduces oxygen to $\mathrm{O}_{2}^{-}$and $\mathrm{H}_{2} \mathrm{O}_{2}$, and these two products can react to form ${ }^{\circ} \mathrm{OH}$ (Beauchamp \& Fridovich, 1970). Without the catalytic effect of trace metals this is a sluggish process, but the reaction proceeds briskly in the presence of $\mathrm{Fe}$ (III) complexes, due to reduction of the latter by $\mathrm{O}_{2}^{-}$and the further reaction of $\mathrm{Fe}^{2+}$ with $\mathrm{H}_{2} \mathrm{O}_{2}$ (Weinstein \& Bielski, 1979). Damage to DNA by the xanthine-xanthine oxidase-iron system could be prevented with SOD and catalase, suggesting that both $\mathrm{O}_{2}^{-}$and $\mathrm{H}_{2} \mathrm{O}_{2}$ are essential for its injurious effect. Also, since iron was required, and mannitol and thiourea are scavengers with specificity for $\mathrm{OH}$ (Dorfman \& Adams, 1973), we concluded that this oxidant was the most injurious toxic oxygen species for bacterial DNA. We have shown that toxic oxygen species (especially $\mathrm{OH}$ ) can induce extensive breakdown of bacterial (chromosomal and plasmid) DNA. When chromosomal DNA was incubated with xanthine plus xanthine oxidase plus excess iron degradation of DNA into numerous nucleotides was observed. Nucleases were not needed for this breakdown.

In addition, xanthine plus xanthine oxidase plus iron interfered rapidly with the biological activity of plasmid and chromosomal DNA : both kinds of DNA were unable to transform recipient cells after incubation with the above system. In humans, virtually every cell contains systems in which oxygen species are generated (e.g. the mitochondrial system or enzymes such as xanthine oxidase). Polymorphonuclear and mononuclear leucocytes especially possess a potent toxic oxygen-species-generating system. Therefore, it is possible that in these cells, as well as in other cell types, damage to DNA can occur (Birnboim, 1982). Indeed, it has recently been shown that leucocyte-derived toxic oxygen species can induce mutations in bacterial DNA (Weitzman \& Stossel, 1982).

Our studies suggest that the beneficial effects of toxic oxygen species not only include the killing of bacteria, but also the protection of the host by preventing bacteria from acquiring or maintaining drug resistance by destroying of transferable information on plasmid DNA.

We thank Mrs A. McArthur-Noom and Miss Y. M. Joseph for secretarial assistance in the preparation of this manuscript. 


\section{REFERENCES}

Armel, P. R., Strniste, G. F. \& Wallace, S. S (1977). Studies on Escherichia coli X-ray endonuclease specificity. Roles of hydroxyl radical in the production of DNA lesions. Radiation Research 69, 328-338.

BABIOR, B. M., KiPNES, R. S. \& CURNeTte, J. T. (1973). Biological defense mechanisms: the production by leukocytes of superoxide, a potential bactericidal agent. Journal of Clinical Investigation 52, 741-744.

Badwey, J. A. \& Karnovsky, M. L. (1980). Active oxygen species and the functions of phagocytic leukocytes. Annual Review of Biochemistry 49,695726.

Beauchamp, C. \& Fridovich, I. (1970). A mechanism for the production of ethylene from methional. The generation of hydroxyl radical by xanthine oxidase. Journal of Biological Chemistry 245, 4641-4646.

Bergmans, H. E. N., van Die, J. M. \& Hoekstra, W. P. M. (1981). Transformation in Escherichia coli: stages in the process. Journal of Bacteriology 146, 564-570.

BIRNBOIM, H. C. (1982). Factors which affect DNA strand breakage in human leukocytes exposed to a tumor promotor, phorbor myristate acetate. Canadian Journal of Physiology and Pharmacology 60, 13591366.

Birnboim, H. C. \& Doly, J. (1979). A rapid alkaline extraction procedure for screening recombinant plasmid DNA. Nucleic Acids Research 7, 1513-1523.

Cosloy, S. D. \& Oishi, M. (1973). The nature of the transformation process in Escherichia coli K12. Molecular and General Genetics 124, 1-10.

Dorfman, L. M. \& ADAMs, G. E. (1973). Reactivity of the hydroxyl radical in aqueous solutions. National Standard Reference Data System, US Department of Commerce and National Bureau of Standards, no. 46, pp. 1-59.

ElsBaCH, P. (1980). Degradation of microorganisms by phagocytic cells. Reviews of Infectious Diseases 2, 106-128.

KleBANOFF, S. J. (1975). Antimicrobial mechanism in neutrophillic polymorphonuclear leukocytes. Seminars in Hematology 12, 117-142.

Lesko, S. A., LoRentzen, R. J. \& Ts'o, P. O. P. (1980).
Role of superoxide in deoxyribonucleic acid strand scission. Biochemistry 19, 3023-3028.

MCCORD, J. M. (1974). Free radicals and inflammation: protection of synovial fluid by superoxide dismutase. Science 185, 529-531.

MCCORD, J. M. (1985). Oxygen-derived free radicals in postischemic tissue injury. New England Journal of Medicine 312, 159-163.

McPhail, L. C., Henson, P. M. \& Johnston, R. B. (1981). Respiratory burst enzyme in human neutrophils. Evidence for multiple mechanisms of activation. Journal of Clinical Investigation 67, 710-716.

MYERS, L. S., JR (1973). Free radical damage of nucleic acids and their components by ionizing radiation. Federation Proceedings. Federation of American Societies for Experimental Biology 32, 1882-1894.

Rowley, D. A. \& Halliwell, B. (1983). DNA damage by superoxide-generating systems in relation to the mechanism of action of the anti-tumor antibiotic adriamycin. Biochimica et biophysica acta 761, 86-93.

Rozenberg-Arska, M., Salters, E. C., van Strijp, J. A., Hoekstra, W. P. M. \& Verhoef, J. (1984a). Degradation of Escherichia coli chromosomal and plasmid DNA in serum. Journal of General Microbiology 130, 217-222.

Rozenberg-Arska, M., van StriJp, J. A., Hoekstra, W. P. M. \& VERHOEF, J. (1984b). Effect of human polymorphonuclear and mononuclear leukocytes on chromosomal and plasmid DNA of Escherichia coli. Role of acid DNase. Journal of Clinical Investigation 73, 1254-1262.

Sausville, E. A., Peisach, J. P. \& Horovitz, P. B. (1978). Effect of chelating agents and metal ions on the degradation of DNA by bleomycin. Biochemistry 14, 2740-2746.

Weinstein, J. \& BielsKi, B. H. J. (1979). Kinetics of interaction of $\mathrm{HO}_{2}$ and $\mathrm{O}_{2}^{-}$radicals with hydrogen peroxide. The Haber-Weiss reaction. Journal of the American Chemical Society 101, 58-62.

Weitzman, S. A. \& Srossel, T. P. (1982). Effects of oxygen radical scavengers and antioxidants on phagocyte-induced mutagenesis. Journal of Immuno$\log y 128,2770-2772$. 